\title{
PENANAMAN MORINGA OLEIFERA UNTUK PENINGKATAN KESEHATAN MASYARAKAT DAN PENGHIJAUAN DI DUSUN TAMBAK REJO MOJOKERTO
}

\author{
Moringa Oleifera Planting For Improving Community Health And Greening In Tambak \\ Rejo Village Mojokerto District
}

\author{
Tri Peni, Tri Ratnaningsih, Siti Indatul Laili \\ STIKes Bina Sehat PPNI Mojokerto \\ peni.ners@gmail.com, triratna83@yahoo.co.id, sitiindatullaili@yahoo.co.id
}

\begin{abstract}
ABSTRAK
Dusun Tambak Rejo mempunyai wilayah yang cukup gersang pada musim kemarau dan pada daerah yang dialiri sungai mengalami banjir pada musim hujan. Pada musim kemarau kondisi pemukiman panas karena sedikit tanaman yang bisa tumbuh. Hanya tanaman tertentu yang bisa hidup subur di daerah tersebut. Tanaman kelor merupakan tanaman yang mudah untuk ditanam dan juga mempunyai daya tahan yang sangat baik jika terjadi perubahan musim. Tanaman kelor yang mempunyai nama latin Moringa oleifera dapat tumbuh tinggi hingga mencapai 7 meter atau bahkan ada 12 meter. Pohon kelor selain untuk penghijauan pada lahan yang gersang, mempunyai banyak manfaat dibidang kesehatan baik itu daun, kulit batang atau juga buah serta bijinya. Daunnya bisa di jadikan sayur yang bermanfaat untuk meningkatkan daya tahan tubuh dan memperbaiki system pencernaan. Prosedur kegiatan pengabdian masyarakat ini dimulai dari tim melakukan koordinasi dengan mitra. Pelaksanaan di awali dengan koordinasi dengan mitra untuk menentukan jadwal kegiatan. Sosialisasi manfaat tanaman kelor (moringa oleifera) dilakukan di balai dusun Tambak Rejo, diikuti oleh 68 warga. Setelah sosialisasi dilanjutkan dengan pembagian bibit kelor (moringa oleifera) kepada masyarakat yang hadir. Tim memberikan contoh penanaman dan memantau proses penanaman moringa oleifera di Dusun Tambak Rejo. Hasil evaluasi tanaman moringa oleifera tumbuh dengan baik dan terawat. Warga sudah memanfaatkan daunnya untuk di konsumsi sebagai sayur menu harian. Target capaian pengabdian masyarakat ini adalah penghijauan pada lahan gersang dan pemanfaatan moringa oleifera untuk peningkatan kesehatan masyarakat.
\end{abstract}

Kata Kunci : Moringa Oleifera, kesehatan

\section{ABSTRACT}

Tambak Rejo Village has a fairly arid area in the dry season and in areas that are flooded by rivers experiencing flooding in the rainy season. In the dry season the conditions of the settlement are hot because few plants can grow. Only certain plants can flourish in the area. Moringa plants are plants that are easy to plant and also have very good endurance in the event of seasonal changes. Moringa plants which have the Latin name Moringa oleifera can grow up to 7 meters high or even 12 meters tall. Moringa tree in addition to greening on arid land, has many benefits in the field of health both leaves, bark or fruit and seeds. The leaves can be made into useful vegetables to increase endurance and improve the digestive system. The procedure of this community service activity starts from the team coordinating with partners. The implementation begins with coordination with partners to determine the schedule of activities. The socialization of the benefits of moringa oleifera was carried out in Tambak Rejo Village, attended by 68 residents. After the socialization continued with the distribution of Moringa oleifera seeds to the people who attended. The team gave examples of planting and monitored the process of planting moringa oleifera in Tambak Rejo Village. The results of the evaluation of Moringa oleifera plants grow well and are well groomed. Residents have used the leaves for consumption as a daily vegetable menu. The targets of community service are greening on arid land and the use of moringa oleifera to improve public health.

Keywords : Moringa Oleifera, health

\section{PENDAHULUAN}

Dusun Tambak Rejo

merupakan salah satu dusun di Desa Gayaman yang sebagian besar penduduknya mempunyai mata pencaharian sebagai petani dan wiraswasta. Beberapa wilayah di Dusun 
tersebut dialiri suangai yang tiap musim hujan meluap yang mengakibatkan banjir pada daerah sekitar aliran sungai tersebut. Pada musim kemarau terlihat cukup gersang, karena minimnya tanaman yang tumbuh di daerah tersebut. Hanya tanaman tertentu yang bisa hidup subur di daerah tersebut. Kepedualian masyarakat untuk bercocok tanam pada musim kemarau rendah, karena jarang yang berhasil tumbuh dengan baik. Hanya daerah persawahan yang masih bisa di tanami karena tersedianya fasilitas pengairan buatan. Sedangkan daerah pemukiman atau sekitar rumah pada musim kemarau tanaman tidak bisa tumbuh dengan baik.

Tanaman Kelor merupakan tanaman yang mudah untuk ditanam dan juga mempunyai daya tahan yang sangat baik jika terjadi perubahan musim. Tanaman Kelor yang mempunyai nama latin Moringa oleifera dapat tumbuh tinggi hingga mencapai 7 meter atau bahkan ada 12 meter. Pohon kelor selain untuk penghijauan pada lahan yang gersang, mempunyai banyak manfaat dibidang kesehatan baik itu daun, kulit batang atau juga buah serta bijinya. Daunnya bisa di jadikan sayur yang bermanfaat untuk meningkatkan daya tahan tubuh dan memperbaiki system pencernaan.(Gopalakrishnan, Doriya and Kumar, 2016),(Hasanah, 2018)

Berdasarkan survei lokasi di dusun Tambak Rejo, hanya ada beberapa warga yang menanam kelor. Walaupun tanaman kelor bisa tumbuh dengan baik di tanah gersang, masyarakat belum tertarik untuk menanamnya karena tidak memahami manfaat dari tanaman tersebut. Warga yang menanam hanya di manfaatkan untuk pakan ternak dan ada sedikit warga yang di gunakan untuk sayur dan itupun jarang dilakukan karena cara pengolahanya yang kurang tepat sehingga rasanya kurang enak. Pada saat wawancara dengan beberapa warga, mereka belum tau manfaat tanaman kelor bagi kesehatan.

Kebijakan pemanfaatan lahan gersang dan peningkatan kesehatan diperlukan kesadaran masyarakat dalam melakukan penghijauan dan pemahaman pentingnya asupan gizi yang cukup untuk meningkatkan derajat kesehatan. Tanaman kelor mempunyai kandungan nutrisi yang sangat baik untuk asupan gizi sehingga selain untuk penghijauan bisa juga diolah untuk asupan gizi masyarakat. Partisipasi masyarakat akan terbentuk dengan baik apabila terjadi perubahan perilaku yang baik dalam menjaga lingkungan.

\section{METODE}

Kegiatan "Penanaman pohon Moringa

Oleifera (kelor) untuk penghijauan dan peningkatan kesehatan masyarakat dilaksanakan dengan metode pendekatan sebagai berikut:

1. Langkah pertama: Pemberian pendidikan kesehatan tentang pencegahan penyebaran penyakit akibat banjir yang bertujuan meningkatkan pengetahuan masyarakat dan menjelaskan manfaat pohon kelor untuk penghijauan sekaligus sebagai bahan nurisi alami untuk meningkatkan kesehatan.

Langkah yang dilakukan yaitu melakukan koordinasi dengan Kepala Desa, kepala RW dan Kepala RT Dusun Tambak Rejo Desa Gayaman untuk mengundang masyarakat. Tempat pelaksanaan di balai Dusun Tambak Rejo. Waktu memberikan pendidikan kesehatan dilakukan pada tanggal 30 September 2019. Pelaksanaan di awali dengan memberikan materi dengan metode ceramah, diskusi dan demontrasi penanaman bibit pohon kelor

2. Langkah ke dua : Penanaman bibit pohon kelor di lahan kosong bersama masyarakat Dusun Tambak Rejo.

3. Monitoring dan evaluasi.

Monitoring dilakukan dengan cara berkoordinasi dengan kader desa untuk memotivasi masyarakat dalam merawat bibit pohon kelor dan menjaga sanitasi lingkungan. Target keberhasilan program: penghijauan dan peningkatan derajat kesehatan masyarakat dengan pemanfaatan tanaman moringa oleifera.

Evaluasi dilakukan dengan cara memantau pertumbuhan pohon kelor dan pemanfaatan daun dan bijinya sebagai nutrisi yang dapat meningkatkan sistem imun.

\section{HASIL DAN PEMBAHASAN}

Hasil kegiatan pengabdian masyarakat "Penanaman Moringa Oleifera untuk meningkatkan kesehatan masyarakat dan 
penghijauan" di Dusun Tambak Rejo Desa Gayaman dapat dijelaskan sebagai berikut:

Tim pelaksana Pengabdian Masyarakat mengajukan perijinan ke Kepala Desa Gayaman dan melakukan sosialisasi kepada masyarakat yang dibantu oleh tim penggerak PKK Dusun Tambak Rejo. Kegiatan sosialisasi dilaksanakan di Balai dusun Tambak Rejo Desa Gayaman yang di hadiri oleh 68 orang. Masyarakat kelihatan antusias mengikuti kegiatan sosialisasi. Kegiatan sosialisasi meliputi penjelasan factor - factor yang mempengaruhi kesehatan dan perkembangan anak dan manfaat tanaman moringa oleifera untuk kesehatan. Tim PKM mengusulkan tanaman moringa oleifera karena selaian untuk penghijauan juga banyak manfaatnya untuk kesehatan.

Moringa oleifera merupakan tanaman yang mudah di tanam dan bisa hidup di berbagai cuaca. Kelor (Moringa oleifera) sangat mudah ditanam baik dengan menggunakan stek maupun biji. Penanaman dengan stek merupakan praktek paling umum dilakukan sesuai dengan fungsinya sebagai batas tanah, pagar hidup atau batang perambat. Perbanyakan dengan stek cenderung memberikan biomassa yang lebih banyak karena tanaman cenderung menghasilkan banyak cabang yang rimbun sedangkan perbanyakan dengan biji menyebabkan tanaman cenderung tumbuh ke atas dengan batang utama atau percabangan yang sedikit (Krisnadi, 2014). Tanaman kelor dapat tumbuh dengan cepat, sangat bertoleransi dengan iklim yang ekstrim serta buah dan daunnya dapat disimpan sebagai bahan pangan bergizi pada odd-season ketika makanan yang tersedia sangat terbatas (Small, 2012). Manfaat dan khasiat tanaman kelor (Moringa oleifera) terdapat pada semua bangian tanaman baik daun, batang, akar maupun biji. Kandungan nutrisi yang cukup tinggi menjadikan kelor memiliki sifat fungsional bagi kesehatan serta mengatasi kekurangan nutrisi. Untuk memenuhi kebutuhan nutrisi yang bersumber dari kelor dapat dilakukan dengan mengkonsumsi kelor dalam berbagai sajian, diantaranya sebagai bahan sayuran, aneka makanan , minuman dan camilan (Aminah, Ramdhan and Yanis, 2015). (Offor IF, Ehiri
RC, 2014) mengatakan bahwa diperkirakan terdapat paling tidak 300 penyakit yang dapat disembuhkan dengan mengonsumsi atau menggunakan suplemen dengan bahan dasar tanaman kelor, selain itu daun tanaman kelor kaya akan protein, vitamin $\mathrm{A}$, vitamin $\mathrm{B}, \mathrm{C}$, dan mineral.

Kegiatan selanjutnya pembagian 100 bibit moringa oleifera kepada masyarakat oleh Tim PKM. Penduduk di Dusun Tambak Rejo sebagian besar mempunyai pekarangan yang cukup untuk menanam bibit moringa oleifera. Setiap warga yang hadir mendapatkan 1 buah bibit. Warga antusias menanam di area sekitar rumah dengan harapan mudah dalam memanen daunya untuk di olah sebagai menu keseharian. Tim PKM selain membagi bibit juga mengajari cara pengolahannya sebagai menu sehat yang dapat meningkatkan derajat kesehatan masyarakat .

Kegiatan pengabdian masyarakat diakhiri dengan penanaman bibit moringa oleifera di belakang balai dusun Tambak rejo yang di saksikan oleh warga dan selanjutnya diikuti oleh warga untuk menanam di pekarangan rumahnya masing-masing. Dalam melaksanakan kegiatan pengabmas Tim PKM melibatkan mahasiswa mulai dari kegiatan sosialisasi sampai penanaman bibit moringa oleifera. Untuk memantau ketepatan dalam penanaman Moringa Oleifera Tim PKM keliling ke rumah warga untuk observasi ketepatan dalam penanaman. Hasil monitoring diketahui pohon kelor sudah ditanam di rumah warga dan mendapat perawatan yang baik sehingga tumbuh subur. Berdasarkan hasil wawancara warga sudah memanfaatkan daunnya untuk di konsumsi sebagai sayur menu harian.

\section{KESIMPULAN}

1. Masyarakat antusias untuk melakukan penghijauan dengan penanaman moringa aloefera (pohon kelor) yang dapat di manfaatkan sebagai nutrisi kesehatan untuk keluarga.

Hasil monitoring pohon kelor sudah ditanam di lahan kosong atau pekarangan warga dan tumbuh subur karena mendapat perawatan yang baik. Warga sudah 
memanfaatnya daunya untuk di konsumsi sebagai sayur menu harian.

\section{DAFTAR PUSTAKA}

Aminah, S., Ramdhan, T. and Yanis, M. (2015) 'Syarifah Aminah et. al.: Kandungan Nutrisi dan Sifat Fungsional Tanaman Kelor (Moringa oleifera )', Buletin Pertanian Perkotaan, 5(30), pp. 35-44.

Gopalakrishnan, L., Doriya, K. and Kumar, D. S. (2016) 'Moringa oleifera: A review on nutritive importance and its medicinal application', Food Science and Human Wellness. Beijing Academy of Food Sciences., 5(2), pp. 49-56. doi: 10.1016/j.fshw.2016.04.001.

Hasanah (2018) Pengaruh Pemambahan Sari daun Kelor dan sari Stroberi Terhadap hasil Uji Organoleptik pada Permen
Karamel Susu, Skripsi Program Studi Biologi Universitas Sanata Dharma Yogyakarta.

Krisnadi (2014) 'Kelor Super Nutrisi.', Pusat Informasi dan Pengembangan Tanaman Kelor Indonesia. LSM-MEPELING., p. 141. doi: 10.1017/CBO9781107415324.004.

Offor IF, Ehiri RC, N. C. (2014) Proximate Analysis and heavy matal composition of dried Moringao oleifera leaves from Oshiri Onicha L.G.A Ebonyi State, Nigeria., IOSR journal of environmental Sciencience, Toxicology and Food technology.

Small, E. (2012) Top 100 exotic food plant. New York (US):CRC Press. 